GEOHYDROLOGY AND GROUND-WATER AVAILABILITY

IN WESTERN MARSHALL AND EASTERN MORGAN COUNTIES, ALABAMA

By C.R. Bossong

U.S. GEOLOGICAL SURVEY

Water-Resources Investigations Report 91-4121

In cooperation with the

CITY OF ARAB WATERWORKS BOARD

Tuscaloosa, Alabama

1992 


\section{U.S. DEPARTMENT OF THE INTERIOR}

MANUEL LUJAN, JR., Secretary

U.S. GEOLOGICAL SURVEY

Dallas L. Peck, Director

For additional information write to:

District Chief

U.S. Geological Survey

52019 th Avenue

Tuscaloosa, Alabama 35401
Copies of this report can be purchased from:

U.S. Geological Survey Books and Open-File Reports Box 25425, Federal Center Denver, Colorado 80225 
Abstract $\ldots \ldots \ldots \ldots \ldots \ldots \ldots \ldots \ldots \ldots \ldots \ldots \ldots \ldots \ldots \ldots \ldots \ldots \ldots \ldots \ldots \ldots \ldots$

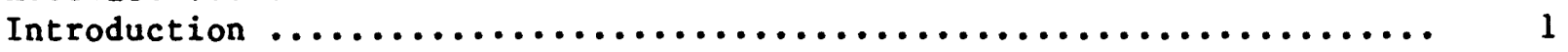

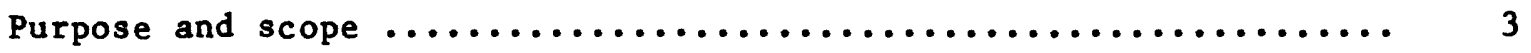

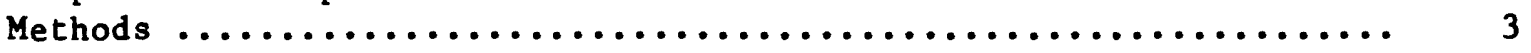

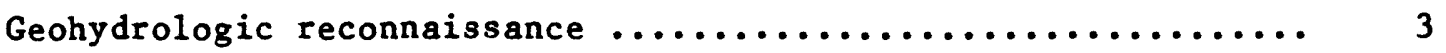

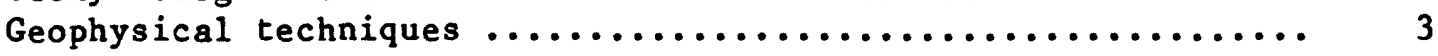

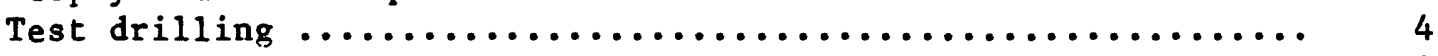

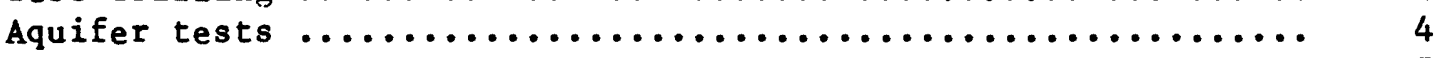

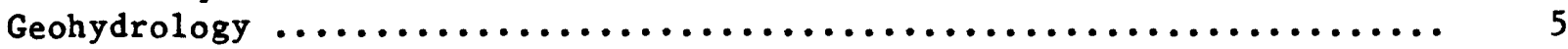

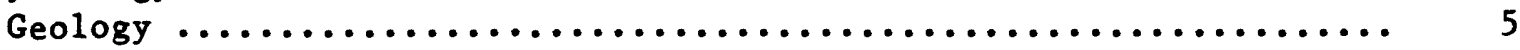

Stratigraphy and water-bearing properties.................. 8

Ordovician, Silurian, and Devonian formations ............ 8

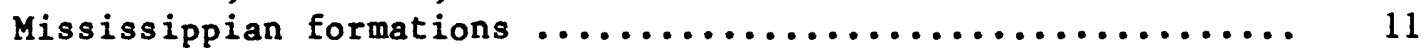

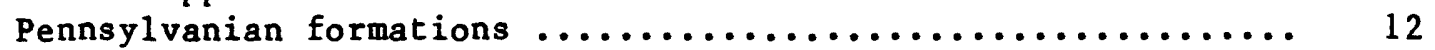

Ground-water recharge, movement, and discharge $\ldots \ldots \ldots \ldots \ldots \ldots \ldots \ldots 12$

Ground-water availability $\ldots \ldots \ldots \ldots \ldots \ldots \ldots \ldots \ldots \ldots \ldots \ldots \ldots \ldots \ldots \ldots \ldots \ldots \ldots$

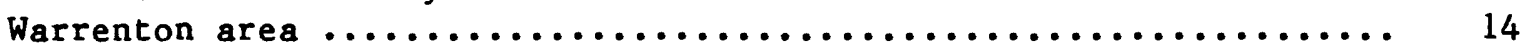

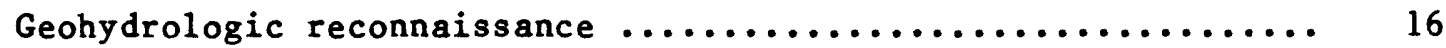

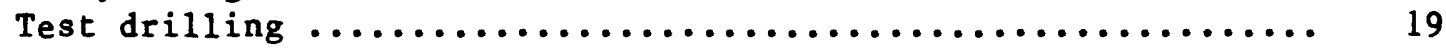

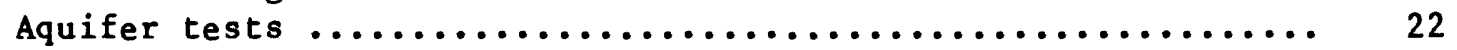

Brind ley Mountain area ................................ 24

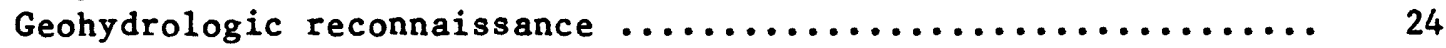

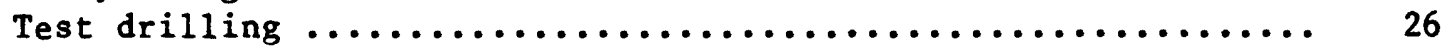

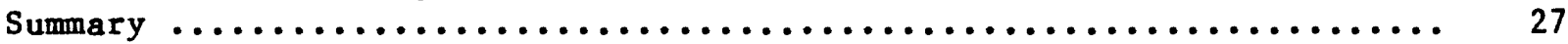

Selected references $. . . \ldots \ldots \ldots \ldots \ldots \ldots \ldots \ldots \ldots \ldots \ldots \ldots \ldots \ldots \ldots \ldots \ldots \ldots \ldots \ldots . . \ldots$ 


\section{ILLUSTRATIONS}

Page

Figure 1. Map showing location of study area $\ldots \ldots \ldots \ldots \ldots \ldots \ldots \ldots \ldots \ldots \ldots$

2. Physiographic map of the study area..................... 6

3. Generalized geologic map and section of the study area ...... 7

4. Hydrographs of daily discharge for Town Creek near Geraldine and Flint River near Chase ................. 13

5. Map showing generalized geology, locations of test wells, and geologic sections in Warrenton area $\ldots \ldots \ldots \ldots \ldots \ldots \ldots$

6. Caliper logs for test wells $1,2,3,4$, and $5 \ldots \ldots \ldots \ldots \ldots \ldots . . \ldots$

7. Graph showing drawdown and time for step-drawdown test for well AD-1, September 22, $1987 \ldots \ldots \ldots \ldots \ldots \ldots \ldots \ldots \ldots \ldots . \ldots \ldots$

8. Map showing locations of test wells in Brindley Mountain area. 25

\section{TABLES}

Table 1. Sumary of geologic units in the study area and their water-bearing properties ......................... 9

2. Records of water wells in the study area $\ldots \ldots \ldots \ldots \ldots \ldots \ldots \ldots \ldots 10$

3 . Records of test wells in the study area $\ldots \ldots \ldots \ldots \ldots \ldots \ldots \ldots \ldots 15$ 
CONVERSION FACTORS AND VERTICAL DATUM

\begin{tabular}{|c|c|c|}
\hline Multiply & by & To obtain \\
\hline inch (in.) & 25.4 & millimeter \\
\hline foot $(f t)$ & 0.3048 & meter \\
\hline mile (mi) & 1.609 & kilometer \\
\hline square mile $\left(\mathrm{mi}^{2}\right)$ & 259 & hectare \\
\hline $\begin{array}{l}\text { cubic foot per second } \\
\text { per square mile } \\
{\left[\left(\mathrm{ft}^{3} / \mathrm{s}\right) / \mathrm{mi}^{2}\right]}\end{array}$ & 0.01093 & $\begin{array}{l}\text { cubic meter per second } \\
\text { per square kilometer }\end{array}$ \\
\hline acre & 4,047 & square meter \\
\hline gallon per minute (gal/min) & 0.06309 & liter per second \\
\hline $\begin{array}{l}\text { gallons per minute per foot } \\
{[(\mathrm{gal} / \mathrm{min}) / \mathrm{ft}]}\end{array}$ & 0.2070 & $\begin{array}{l}\text { liter per second } \\
\text { per meter }\end{array}$ \\
\hline $\begin{array}{l}\text { million gallons per day } \\
(\mathrm{Mgal} / \mathrm{d})\end{array}$ & 0.04381 & cubic meter per second \\
\hline
\end{tabular}

Sea level: In this report "sea level" refers to the National Geodetic Vertical Datum of 1929 (NGVD of 1929)--a geodetic datum derived from a general adjustment of the first-order level nets of both the United States and Canada, formerly called Sea Level Datum of 1929. 


\title{
GEOHYDROLOGY AND GROUND-WATER AVAILABILITY \\ IN WESTERN MARSHALL AND EASTERN MORGAN COUNTIES, ALABAMA
}

By C.R. Bossong

\begin{abstract}
The geohydrology and availability of ground water for an approximately 450 square mile study area in western Marshall and eastern Morgan Counties were investigated by studying the geology and ground-water resources in two distinct geohydrologic settings common in the area. The geohydrologic setting studied in the Warrenton area, where Ordovician through Pennsylvanian rocks are exposed in the Sequatchie anticline, is present in about 20 percent of the study area. The geohydrologic setting studied in the Brindley Mountain area, where relatively undisturbed Mississippian and Pennsylvanian rocks are exposed, is present in about 80 percent of the study area.

Sites were selected for test well construction on the basis of a geohydrologic reconnaissance conducted in each area and supplemented with a limited amount of geophysical work in the Warrenton area. Results of aquifer tests in selected wells were used to evaluate ground-water availability. Test wells in the Warrenton area indicate that yields of greater than 100 gallons per minute are possible from some wells completed in Mississippian carbonate rocks. Test wells in the Brindley Mountain area encountered only relatively small quantities of water from Mississippian carbonate rocks.
\end{abstract}

\section{INTRODUCTION}

The city of Arab is located in southwestern Marshall County about 20 miles south of the city of Huntsville (fig. 1). The City of Arab Waterworks supplies water to most of western Marshall County. During the drought of 1986, the demand for water exceeded the capacity of the system. Because of Arab's proximity to Huntsville and attractiveness for suburban living, population increases continue to increase the demand for water.

In the spring of 1987, the U.S. Geological Survey and the City of Arab Waterworks Board began a cooperative investigation of the geohydrology and ground-water availability in the valley and mountain-top settings which occur throughout northeastern Alabama. This study is part of the U.S. Geological Survey's ground-water program to increase present knowledge of the occurrence of ground water in secondary porosity features.

A general study area of about 450 square miles was defined in western Marshall and eastern Morgan Counties of Alabama. Two relatively small and distinct areas within the overall study area were selected for comprehensive testing because they represent geohydrologic settings that occur over a large 

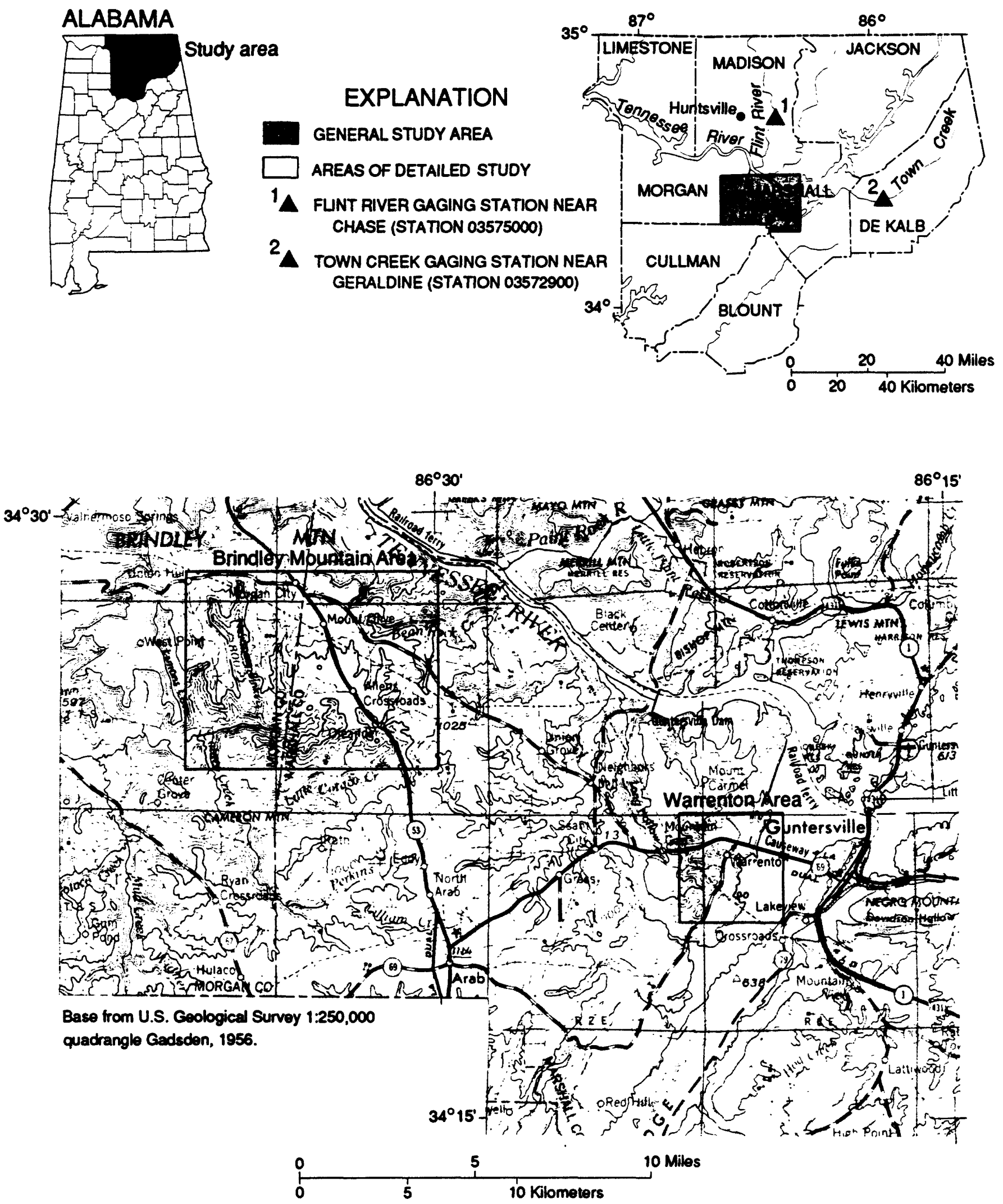

CONTOUR INTERVAL 100 FEET

NATIONAL GEODETIC VERTICAL DATUM OF 1929

Figure 1.-- Location of study area. 
part of the overall study area (fig. 1). The first area represents a geohydrologic setting that occurs in about 20 percent of the study area and is referred to as the Warrenton area. It is located adjacent to the Tennessee River and includes geologic units that have produced large quantities of ground water in nearby areas. The second area represents a geohydrologic setting that occurs in about 80 percent of the study area and is referred to as the Brindley Mountain area. It is located in an upland area adjacent to the Tennessee River Valley where the potential for supply is not well known.

\section{Purpose and Scope}

This report describes the geohydrology and ground-water availability in the study area. Two geohydrologic settings found in the Warrenton and Brindley Mountain areas, that are typical of a large part of the study area, were investigated. The investigation included a geohydrologic reconnaissance, test drilling, and aquifer testing in each of the two areas. In addition, two geophysical techniques were used in the Warrenton area.

\section{Methods}

Several methods were used to investigate ground-water availability in both the Warrenton and Brindley Mountain areas. The methods included geohydrologic reconnaissance, test drilling, and aquifer testing. The methods used also included limited use of two geophysical techniques in the Warrenton area.

\section{Geohydrologic Reconnaissance}

A geohydrologic reconnaissance was conducted to verify and, if possible, add to previously-published geologic information, and to determine as much site specific information about the geology and ground-water resources of the study area as possible prior to test drilling. An analysis of existing information, both geologic and hydrologic, was supplemented with field checks of geologic outcrops.

\section{Geophysical Techniques}

Two geophysical techniques, gravimetric and DC-resistivity, were used to survey selected areas for subsurface cavities or cavity systems. A detailed discussion of the operation and application principles for these techniques is beyond the scope of this report and only a brief discussion of the basic principles is included.

Gravimetric methods use a gravity meter to measure differences in density based on mass attraction between a mass within the gravity meter and the mass of the surrounding area. Gravity readings are reported in International System units of acceleration referred to as gals (centimeters per second squared). A gravity meter would measure less mass attraction over a large open hole than it would over solid earth. Surveyed elevations were determined at a grid of points and for a base station where an initial and arbitrary gravity value was assumed in preparation for the gravity survey made as part of this study. The actual gravity survey procedure involved legs or loops in which 
several readings at the base station were obtained, followed by several readings within the grid, followed by a return to the base station to complete a leg. An integrated correction for tidal variations and meter drift was calculated based on differences in the beginning and ending base station readings. Within the $l e g$, readings were also corrected for elevation and latitude. For a detailed description of the general procedure and corrections, the reader is referred to Dobrin (1976).

DC-resistivity methods use a configuration of electrodes to induce a known current into the ground and measure the drop in potential through a twodimensional area that is perpendicular to the land surface. Measured changes in potential are directly related to the type of material through which the current passes; saltwater, for instance, has much less resistance to current than a consolidated limestone formation. Although the DC-resistivity technique is traditionally used to define shallow stratigraphic relations, it should in theory (Dobrin, 1976; Smith and Randazzo, 1975) also be capable of detecting discrete geometric bodies with unique conducting properties such as cavities. The configuration and spacing of the electrodes affects the configuration of the area through which the current passes. DC-resistivity methods in this study obtained vertical resistivity profiles by using different spacings of the Wenner configuration over a grid of points. The reader is referred to Zohdy and others (1974) for a description of the Wenner method.

\section{Test Drilling}

Test drilling was used to obtain access to the water-bearing units and to obtain geologic information in the study area. Air-rotary drilling methods were used to construct all wells. Eight-inch diameter holes were drilled to bedrock and 6.63 inch galvanized steel casings were then installed. The open holes below casings were drilled with 6-inch diameter percussion bits. The holes were reamed to 8 -inch diameters if additional casing was required to "case off" parts of the well. Geophysical logs were obtained after completion of the wells.

\section{Aquifer Tests}

A pump was installed in selected test wells to evaluate the quantity of water available from test wells. Pumping was restricted to wells which were considered capable of yielding about $100 \mathrm{gal} / \mathrm{min}$ or more of water. In some wells, casings were modified to allow testing of different water-bearing zones. Step-drawdown tests were conducted in wells that had capacities of more than $100 \mathrm{gal} / \mathrm{min}$ and when the water was not excessively turbid. 


\section{GEOHYDROLOGY}

A thick section of Paleozoic rocks that have been folded along a northeastward trending axis crops out in the eastern part of the study area. The remainder of the study area is underlain by the same section of Paleozoic rocks that are nearly flat lying. The rocks include three major aquifers that locally may contain large quantities of ground water, principally in secondary features. The Tennessee River flows through and is the major drainage feature in the study area. The river has been impounded in part of the area to form Guntersville Lake, a large reservoir. The altitude of the minimum navigational pool for Guntersville Lake is 593 feet above sea level (Tennessee Valley Authority, 1954). Downstream of Guntersville Lake, the Tennessee River is at an altitude of about 560 feet. Most other streams originate within the study area and have drainage areas of less than 10 square miles and eventually flow into Guntersville Lake or the Tennessee River. Because most drainage in the study area is either to Guntersville Lake or the Tennessee River, the base level for most of the study area is between 560 to 590 feet.

\section{$\underline{\text { Geology }}$}

The Cumberland Plateau area has been characterized as a series of broad synclinal mountains separated by narrow symmetrical to asymmetrical anticlinal valleys that strike northeastward (Thornbury, 1965). The study area conforms to this description and includes physiographic features such as Brindley Mountain and Sequatchie Valley, which represent synclinal and anticlinal features, respectively (fig. 2 ).

Sapp and Emplaincourt (1975) have subdivided Alabama into physiographic sections and districts. A small part of the study area is in the Moulton Valley district of the Highland Rim section; however, the majority of the study area lies in the Cumberland Plateau section and includes parts of the Jackson County Mountains, Sand Mountain, Sequatchie Valley, and Warrior Basin districts. The Sequatchie Valley district is a relatively narrow, deep, northeast trending valley now partly inundated by Guntersville Lake. The Jackson County Mountains are separated from the Warrior Basin by the Tennessee River. Altitudes on the plateau surface in the Jackson County Mountains and Warrior Basin districts range from about 900 to 1,300 feet. The Sand Mountain district is similar to the Jackson County Mountains district in the study area.

The Warrenton area (fig. 1) is located in the Sequatchie Valley on the northwestern limb of an asymmetrical fold, the Sequatchie anticline (fig. 3 ). Geologic formations may dip almost vertically here and many smaller structural features such as local thrust and high angle faults may also occur. In addition to the major fold and associated structures, a regional structural feature known as the Anniston Lineament Complex (Drahovzal and others, 1975) trends through the area. The Anniston Lineament Complex strikes roughly perpendicular to the fold and, as the name suggests, is actually a series of linear zones consisting of several individual discontinuous and sometimes en-echelon fractures or lineaments. The Anniston Lineament Complex has been 


\section{EXPLANATION}

PHYSIOGRAPHIC DISTRICTS

Moulton Valley

Warrior Basin

Jackson County Mountains

Sequatchie Valley

Sand Mountain

BOUNDARIES

Physiographic section

- - - Physiographic district
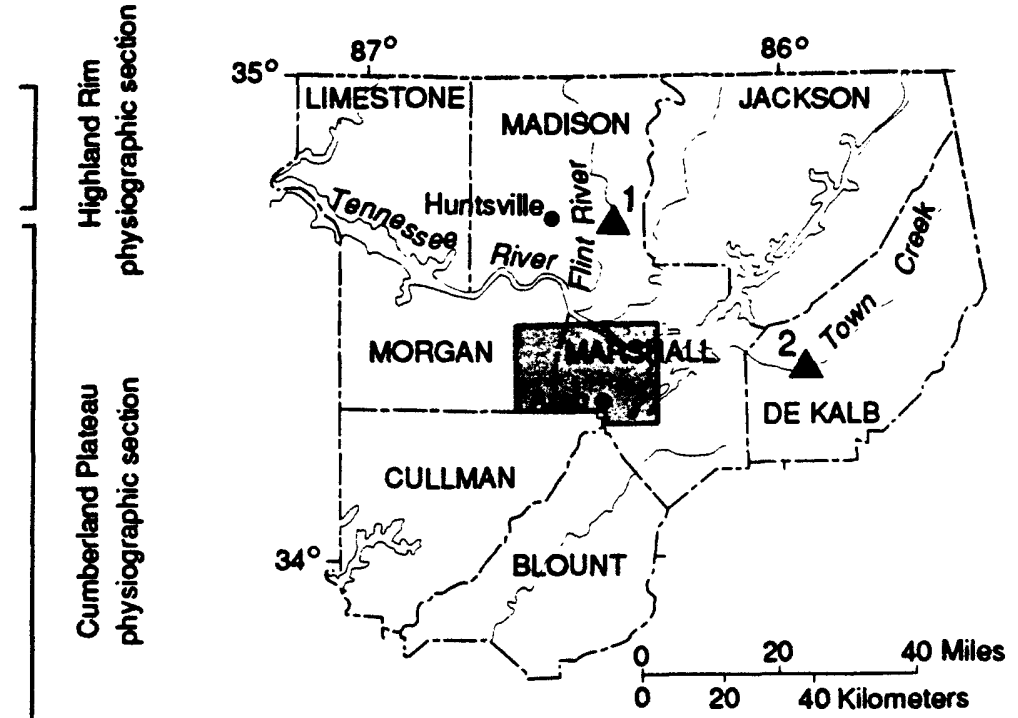

$86^{\circ} 15^{\prime}$

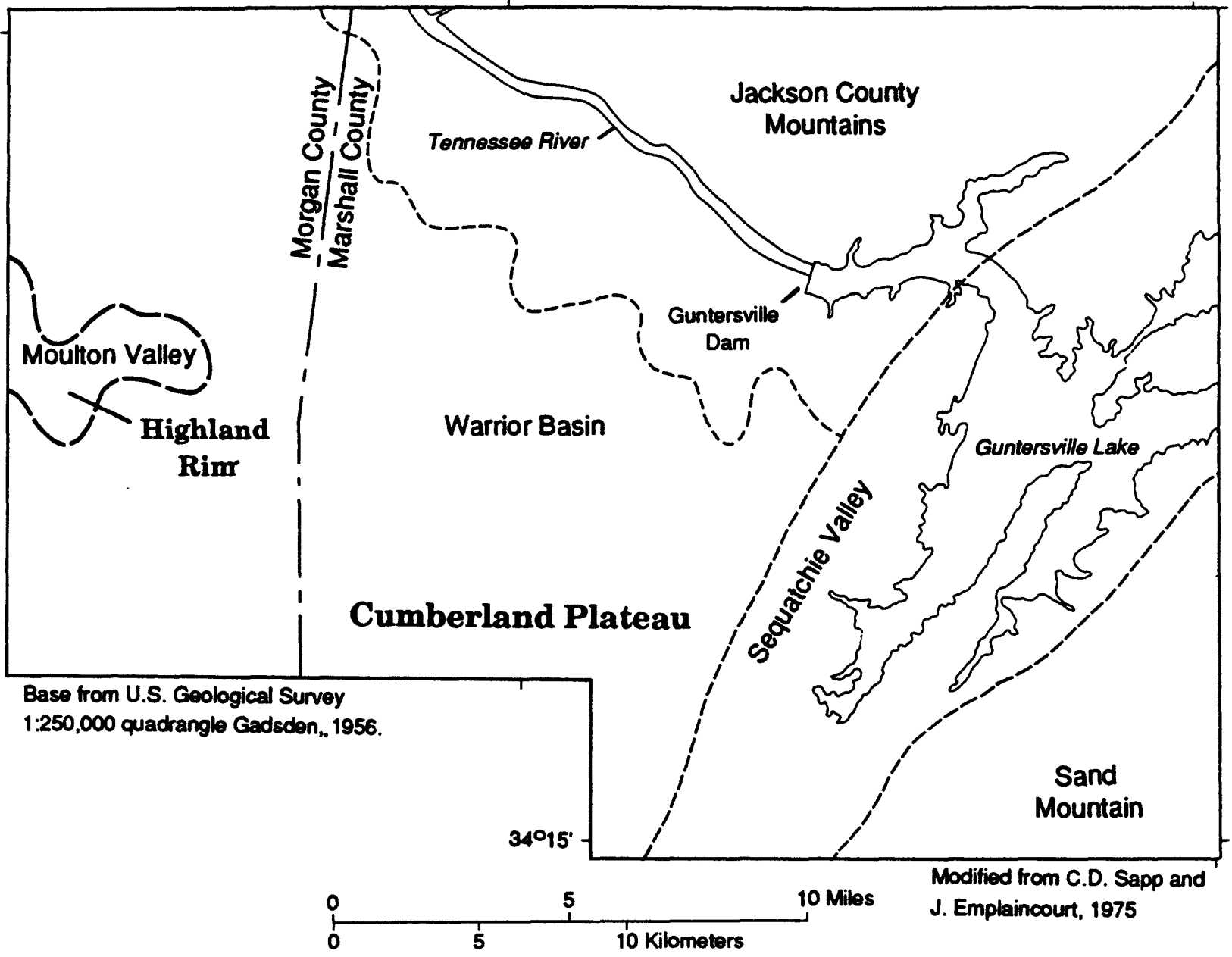

Figure 2.--Physiographic map of the study area. 


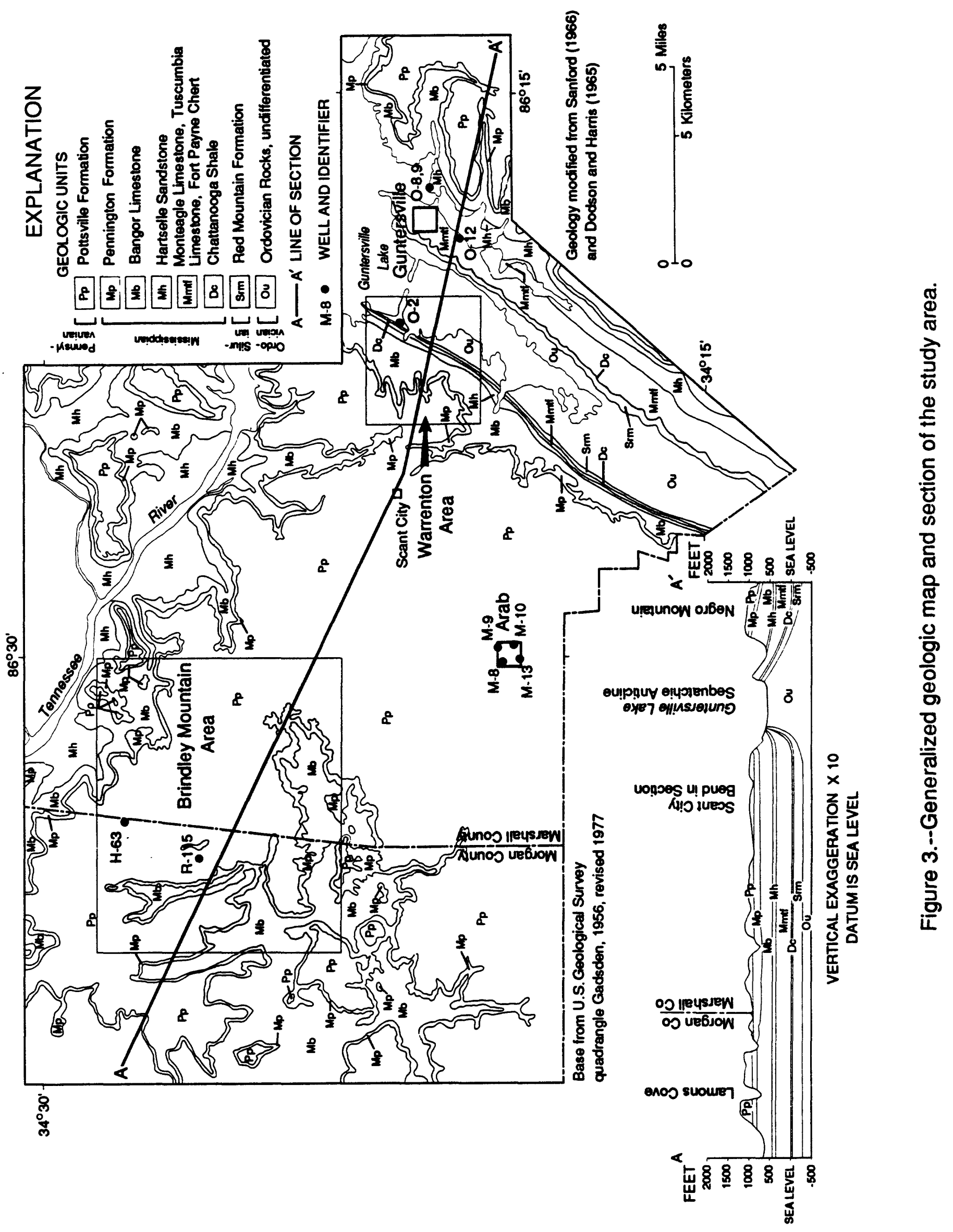


related to high yield wells in southwestern Madison County to the northwest (Drahovzal and others, 1975). Two additional relatively small types of features occur throughout the study area. They are discontinuous vertical fractures referred to as joints and discontinuous fractures parallel to rock layers referred to as bedding-plane openings.

The Brindley Mountain area (fig. 1) is located in the Warrior Basin (fig. 3). Geologic formations are nearly horizontal and structural discontinuities such as the Anniston Lineament Complex are not obvious in the Brindley Mountain area. Rock outcrops in the Brindley Mountain area display joints and bedding-plane openings.

\section{Stratigraphy and Water-Bearing Properties}

A Paleozoic sequence of rocks from middle Ordovician through Lower Pennsylvanian age crops out in the study area (fig. 3, table 1). Three major aquifers are present in these rocks. Two are Mississippian limestone or carbonate rock aquifers that may contain substantial quantities of ground water in secondary features, such as fractures, joints, and bedding-plane openings, that have been solutionally enlarged; the third aquifer is a Pennsylvanian sandstone that contains lesser amounts of water, mostly in weathered sands and also in secondary features that have not been enlarged. The combined thickness of the exposed Paleozoic section is about 2,000 feet. In general, Ordovician carbonate units crop out in the floor of the Sequatchee Valley and are overlain by Silurian and Devonian sandstones and shales that are usually present as conspicuous ridges paralleling both sides of the anticlinal valley. Elsewhere in the study area where the formations are nearly horizontal, Mississippian carbonates, shales, and sandstones crop out on the sides and floors of the valleys and are overlain by Pennsylvanian sandstone which caps broad intervalley areas. Stratigraphic boundaries at the base and top of the Silurian and Devonian systems and at the base of the Pennsylvanian System are reasonably well defined lithologically; however, most other contacts within the sequence are gradational and, with the exception of a few marker beds, are more difficult to determine. A summary of thickness, lithology, and water-bearing properties of each geologic unit is given in table 1. For a detailed discussion of the regional stratigraphy, the reader is referred to Drahovzal and Neathery (1971) and Thomas (1972). A summary of known high-yield wells as well as some wells in which some quality of water information is available is given in table 2 .

\section{Ordovician, Silurian, and Devonian Formations}

The Ordovician System includes four carbonate formations in the study area: the Chickamauga Limestone, Inman Formation, Leipers Limestones, and Sequatchie Formation (table 1). The total thickness of the formations in outcrops is about 300 feet and they generally consist of thin-bedded, clayey to medium-grained, fossiliferous limestones with some shale and secondary iron bearing minerals. Ground water of suitable quantity and quality for domestic supply is available from these units where they crop out; however, it is unlikely that large quantities of ground water may be available to wells from these formations due to their clayey and shaly nature and their limited occurrence in the study area. 
Table 1.--Summary of geologic units in the study area and their water-bearing properties

\begin{tabular}{|c|c|c|c|c|c|}
\hline $\begin{array}{l}\text { Era- } \\
\text { them }\end{array}$ & System & $\begin{array}{c}\text { Stratigraphic } \\
\text { unit }\end{array}$ & $\begin{array}{l}\text { Thickness } \\
\text { (feet) }\end{array}$ & $\begin{array}{l}\text { Principal } \\
\text { lithology }\end{array}$ & $\begin{array}{l}\text { Water-bearing } \\
\text { properties }\end{array}$ \\
\hline & Pennsylvanian & $\begin{array}{l}\text { Pottsville } \\
\text { Formation }\end{array}$ & $\begin{array}{l}\text { up to } \\
300\end{array}$ & $\begin{array}{l}\text { Sandstone, shale, } \\
\text { and coal }\end{array}$ & $\begin{array}{l}\text { As much as } 0.3 \text { Mgal/d (million } \\
\text { gallons per day) may be } \\
\text { available from deep weathered } \\
\text { zones. Most wells yield small } \\
\text { amounts of water. }\end{array}$ \\
\hline & Mississippian & $\begin{array}{l}\text { Pennington } \\
\text { Formation }\end{array}$ & $\begin{array}{l}\text { up to } \\
110\end{array}$ & Shale & $\begin{array}{l}\text { May yield small quantities of } \\
\text { water. }\end{array}$ \\
\hline & & $\begin{array}{l}\text { Bangor } \\
\text { Limestone }\end{array}$ & $\begin{array}{l}\text { up to } \\
380\end{array}$ & $\begin{array}{l}\text { Limestone, clayey } \\
\text { with oolities }\end{array}$ & $\begin{array}{l}\text { May yield large quantities of } \\
\text { water to wells that penetrate } \\
\text { water-bearing solution } \\
\text { features. }\end{array}$ \\
\hline $\mathbf{P}$ & & $\begin{array}{l}\text { Hartselle } \\
\text { Sandstone }\end{array}$ & $0-110$ & $\begin{array}{l}\text { Sandstone with } \\
\text { calcite cement }\end{array}$ & $\begin{array}{l}\text { Yields water adequate for } \\
\text { domestic supplies. }\end{array}$ \\
\hline $\begin{array}{l}a \\
1 \\
e \\
0 \\
z \\
0 \\
i\end{array}$ & & $\begin{array}{l}\text { Monteagle } \\
\text { Limestone, } \\
\text { Tuscumbia } \\
\text { Limestone, } \\
\text { Fort Payne } \\
\text { Chert }\end{array}$ & up to & $\begin{array}{l}\text { Chert and } \\
\text { siliceous } \\
\text { limestone }\end{array}$ & $\begin{array}{l}\text { May yield large quantities of } \\
\text { water to wells that penetrate } \\
\text { water-bearing solution } \\
\text { channels. }\end{array}$ \\
\hline & Devonian & $\begin{array}{l}\text { Chattanooga } \\
\text { Shale }\end{array}$ & $0-50$ & $\begin{array}{l}\text { Shale; } \\
\text { carbonaceous }\end{array}$ & $\begin{array}{l}\text { Yields very little water to } \\
\text { wells, a confining layer. }\end{array}$ \\
\hline & Silurian & $\begin{array}{l}\text { Red Mountain } \\
\text { Formation }\end{array}$ & 200 & $\begin{array}{l}\text { Sandstone with } \\
\text { iron cement }\end{array}$ & $\begin{array}{l}\text { Yields water adequate for } \\
\text { domestic supplies. }\end{array}$ \\
\hline & Ordovician & $\begin{array}{l}\text { Sequatchie } \\
\text { Formation, } \\
\text { Leipers } \\
\text { Limestone, } \\
\text { Inman } \\
\text { Formation, } \\
\text { Chickamauga } \\
\text { Limestone }\end{array}$ & $300+$ & $\begin{array}{l}\text { Limestones; clayey } \\
\text { and fossiliferous }\end{array}$ & $\begin{array}{l}\text { Yields water adequate for } \\
\text { domestic supplies. }\end{array}$ \\
\hline
\end{tabular}




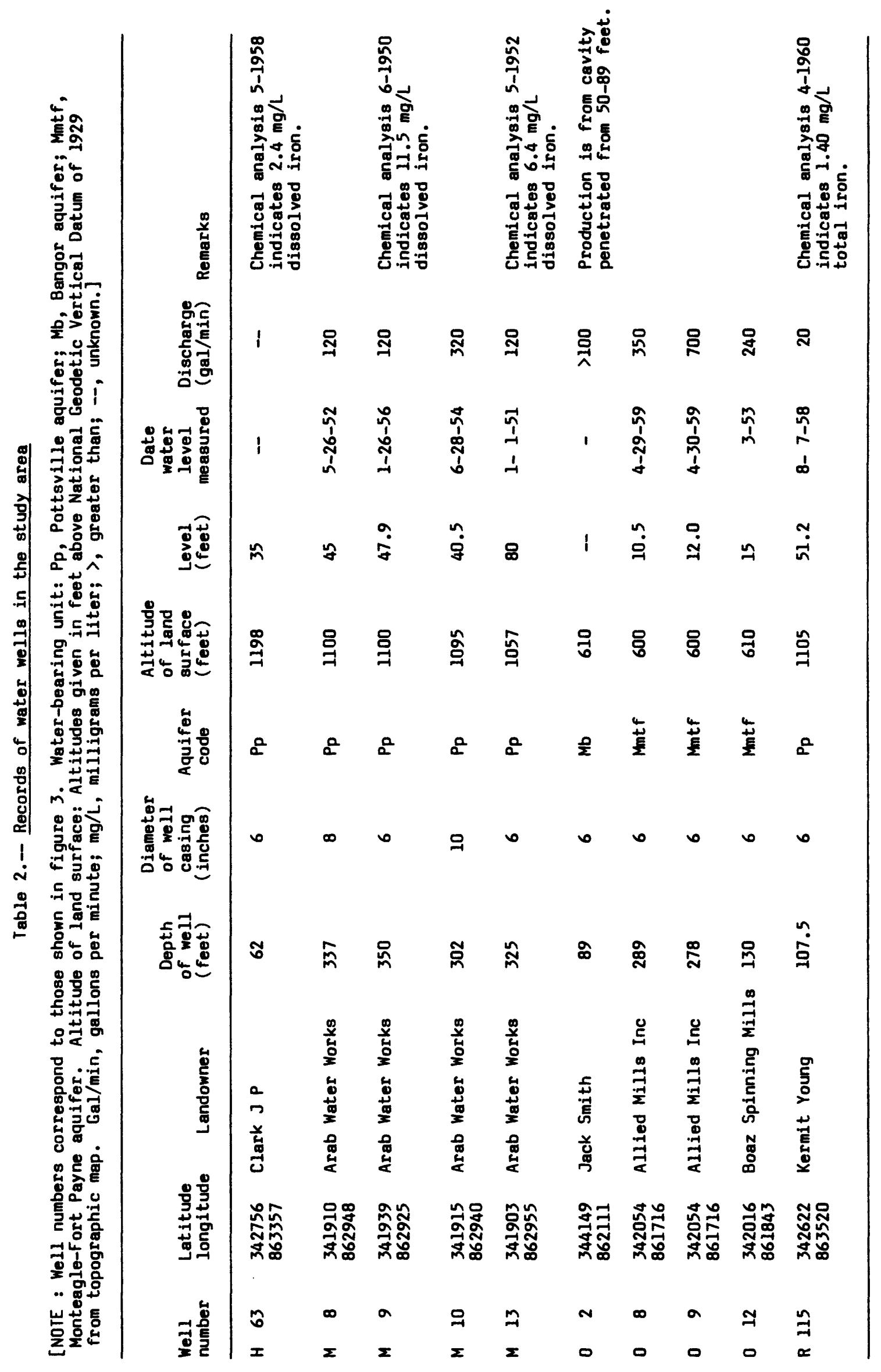


The Silurian System includes only one formation in the study area, the Red Mountain Formation which is about 200 feet thick. The formation consists mostly of ferruginous sandstone interbedded with shale; the Red Mountain is an important source of iron ore in other parts of the State. The Red Mountain Formation is relatively impermeable and generally is not used for water supply.

The Devonian System includes only one formation in the study area, the Chattanooga Shale, which is usually less than 50 feet thick. The formation consists of distinctive black pyritic shale that is an important confining unit. Only small quantities of water that may contain large concentrations of sulfate are available from the Chattanooga Shale.

\section{Mississippian Formations}

The Mississippian System in the study area includes several formations: the Fort Payne Chert, Tuscumbia Limestone, Monteagle Limestone, Hartselle Sandstone, Bangor Limestone, and Pennington Formation. The three lower units are collectively up to 500 feet thick and consist of chert-bearing, fossiliferous, thin- to thick-bedded limestones which may contain lenses of very coarse fossiliferous material and, particularly in the Monteagle, may contain some shale; the Fort Payne Chert is exceptionally cherty near its base. The Hartselle Sandstone, from 0 to 110 feet thick, overlies the Monteagle Limestone and consists of fine-grained well sorted sandstone. The Bangor Limestone is usually about 350 feet thick, and consists of clayey limestone that is less coarse than the lower Mississippian limestones. The Pennington Formation is about 110 feet thick and consists chiefly of multicolored or variegated shale.

Two important aquifers occur in the Mississippian formations. The Monteagle-Fort Payne aquifer includes the Monteagle Limestone, Tuscumbia Limestone, and the Fort Payne Chert. The Bangor aquifer is the Bangor Limestone. The two aquifers are separated by the Hartselle Sandstone which is a confining unit where present.

The primary porosity of the Monteagle-Fort Payne and Bangor aquifers is low because of their indurated nature which developed through cementation processes that filled most original pore space. However, the units contain secondary features such as joints and bedding plane openings through which ground water may move. Because carbonate aquifers are soluble, dissolution processes may enlarge secondary features such as joints and bedding-plane openings and create a network of highly-permeable conduits capable of supplying large quantities of ground water to wells (Stringfield and others, 1974). For instance, some wells that penetrate solution features in the Monteagle-Fort Payne aquifer in nearby Madison County produce 3,000-5,000 $\mathrm{gal} / \mathrm{min}$ (Moffet and Bossong, 1981), and several wells in the study area produce greater than $200 \mathrm{gal} / \mathrm{min}$ from the Monteagle-Fort Payne aquifer (table 2). 


\section{Pennsylvanian Formations}

The Pottsville Formation of Pennsylvanian age consists of as much as 300 feet of indurated interbeds of fine- to coarse-grained, poorly-sorted sandstone and shale with minor amounts of siltstone and coal. The Pottsville Formation is an important aquifer in much of northeastern Alabama due principally to its widespread occurrence. Generally, the Pottsville aquifer does not yield large quantities of water to wells; however, some wells capable of yielding greater than $100 \mathrm{gal} / \mathrm{min}$ have been developed in the Pottsville Formation where it is deeply weathered and consists almost entirely of sands (table 2).

\section{Ground-Water Recharge, Movement, and Discharge}

The source of most water in the study area is precipitation, which averages about 55 inches annually (U.S. Department of Commerce, 1985). The amount of precipitation transported out of the area through streamflow is referred to as runoff. Most remaining precipitation is returned to the atmosphere by evapotranspiration processes. A significant amount of the annual runoff occurs in direct response to precipitation during storms. The actual amount of direct runoff in the study area has not been determined; however, it has been estimated to be about 10 inches for the Tennessee Valley as a whole. This amount is probably representative for many streams in the study area (Zurawski, 1978). The remaining runoff is discharged to streams from aquifers and will be referred to as base flow.

Factors such as geology may affect runoff and recharge quantities. Discharge records (U.S. Geological Survey 1929-86) indicate the average amount of annual runoff in northeastern Alabama varies from about 22 to 28 inches. The largest runoff rates occur in areas such as Brindley Mountain where the Pottsville Formation crops out. The Pottsville Formation is indurated and, consequently, has relatively low primary porosity and permeability. Most precipitation in this setting runs off directly and thus is not available to recharge the local aquifer system. Conversely, recharge to local aquifer systems is greater in areas such as the Warrenton area, where carbonate formations have relatively high porosity and permeability due to solution enlarged joints and fractures. The total runoff is less for the Warrenton area, where carbonate aquifers occur, than for the Brindley Mountain area due principally to less direct runoff during storms. However, base flow is usually greater in the Warrenton area than in the Brindley Mountain area due to greater recharge. Hydrographs of daily flow for Town Creek near Geraldine (station 03572900) and Flint River near Chase (station 03575000), streams which are typical of the Brindley Mountain and Warrenton areas, respectively, illustrate these relations. For example, from late July to the end of September 1976, the base flow of Town Creek receded to nearly $0.01\left(\mathrm{ft}^{3} / \mathrm{s}\right) / \mathrm{mi}^{2}$ while the base flow for the Flint River remained nearly constant at about $1\left(\mathrm{ft}^{3} / \mathrm{s}\right) / \mathrm{mi}^{2}(\mathrm{fig} \cdot 4)$. 


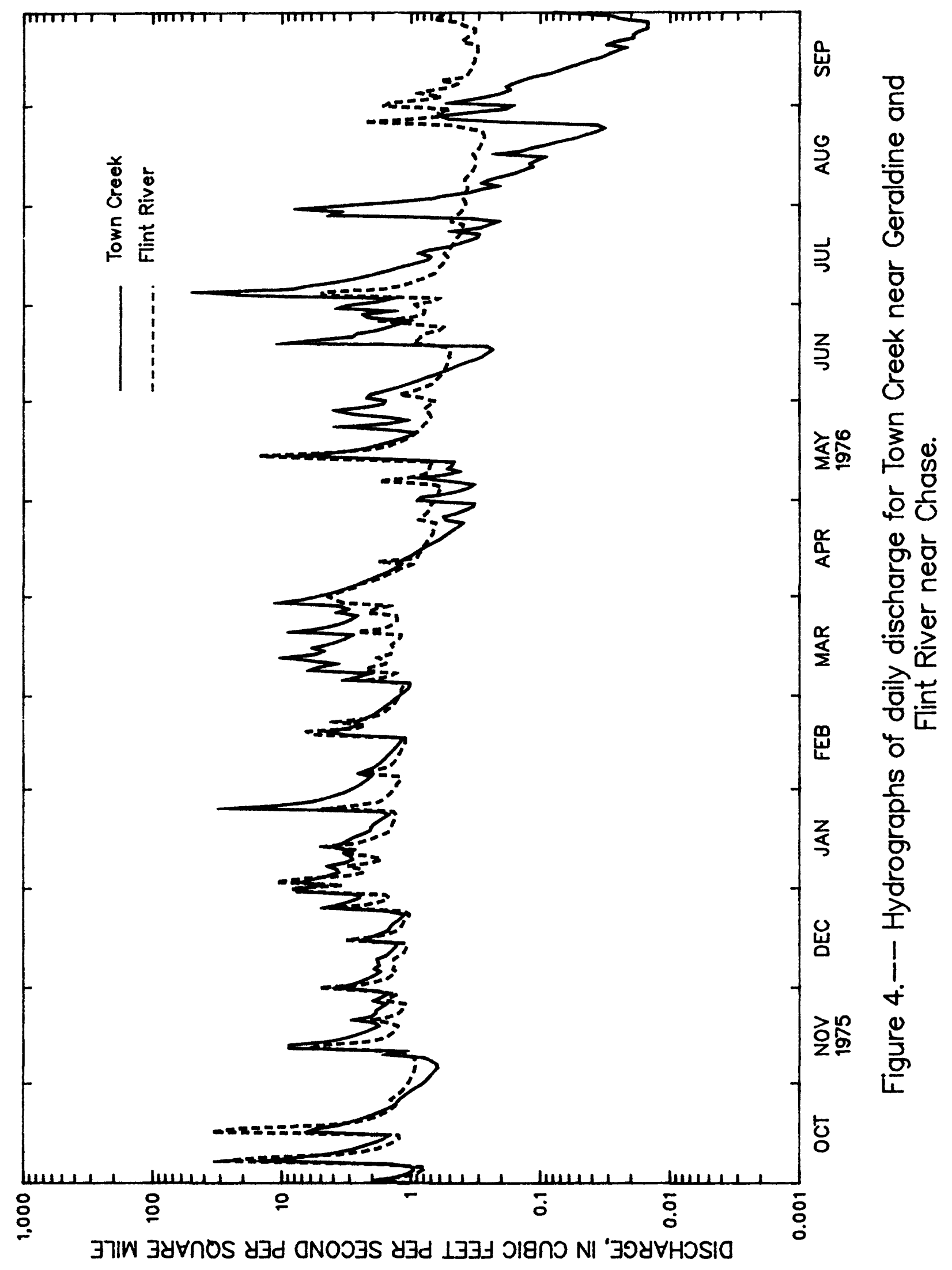


Ground-water movement generally is from topographic highs towards base level or topographic lows, where major surface-drainage features occur; consequently, discharge areas or points are generally lower than recharge areas. If ground water moving downward through a formation encounters a confining layer above the regional base level, the water will form a local or perched water table aquifer. The water level in a perched aquifer will usually fluctuate greatly and generally the volume of water in storage is small and the aquifer is not a reliable source of water. Water levels in aquifers near base level are much more stable than those associated with perched water tables, and these aquifers are generally a good source of water supply with respect to reliability and quantities available.

Ground-water movement in aquifers such as the Monteagle-Fort Payne and Bangor aquifers with secondary features that have been enlarged by dissolution processes may be quite different than in aquifers that do not have enlarged secondary features. Most ground-water flow in aquifers with enlarged secondary features usually takes place in the secondary features. Consequently, water-bearing zones in aquifers with enlarged secondary features may be extremely localized. For example, ground-water flow, in the form of spring discharge, may be concentrated where enlarged secondary features crop out.

\section{GROUND-WATER AVAILABILITY}

Table 2 lists known high-yield wells in the study area as well as wells for which some quality of water information is available; the locations for these wells are shown in figure 3. Most wells that yield greater than 100 gal/min are in the Monteagle-Fort Payne aquifer. Water from wells in the Pottsville aquifer often have greater than $0.3 \mathrm{mg} / \mathrm{L}$ of dissolved iron and some have been abandoned due to problems related to dissolved iron concentrations.

Ground-water availability in the study area was further investigated in the Warrenton and Brindley Mountain areas through test drilling. In each area a geohydrologic reconnaissance was conducted in preparation for test drilling. Findings of the reconnaissance were used to select locations which appeared favorable with respect to ground-water availability. Test wells were constructed at these sites and used to evaluate the ground-water resources. Pumps were installed in wells where test drilling indicated potential yields of more than $100 \mathrm{gal} / \mathrm{min}$. A summary of test well characteristics is given in table 3 .

\section{Warrenton Area}

The geohydrologic setting in the Warrenton area is representative of the Sequatchie Valley district. Three test wells, TW-1, TW-2, and TW-3, were constructed in the Warrenton area. An additional well, $A D-1$, was constructed by the City of Arab Waterworks Board. 


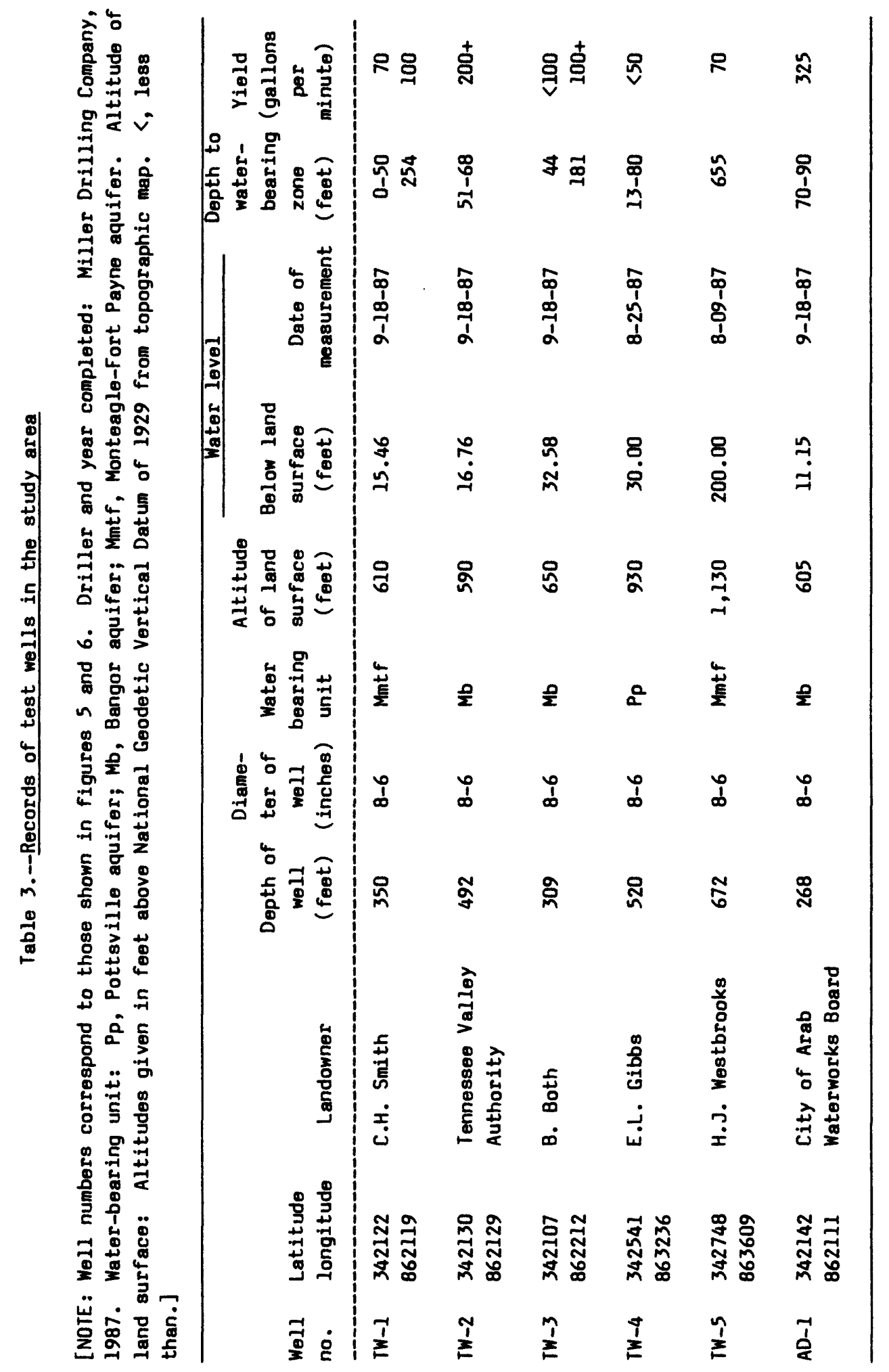


The geology of the Warrenton area was originally mapped in the early 1900 's and published in Adams and others (1926). In 1966 Sanford prepared a more-detailed map (fig. 3) that generally reflected the geology as mapped by Adams and others (1926). A more recent map of the surface geology in the Warrenton area was prepared by Garrett (1973). Garrett's map includes the Brown's Valley fault, a structure not previously mapped, and a different interpretation for outcrops of the Hartselle Sandstone, Monteagle Limestone, Tuscumbia Limestone, and Fort Payne Chert than shown by Adams and others (1926) or Sanford (1966) (fig. 5).

The Anniston Lineament Complex passes through the Warrenton area and may be related to many of the linear features present. Several linear features, many of which coincide with drainage, are apparent on aerial photographs. The traces for some of these features in the Warrenton area are shown in figure 5 . In general, the traces are discontinuous and suggest a rectangular pattern that has one axis generally parallel to the strike of the Anniston Lineament Complex. A rectangular pattern is significant because it increases the occurrence of intersecting fractures, a condition that may enhance solution processes. Rectangular fracture patterns are present throughout much of northern Alabama and have been noted in nearby areas in joints (Sonderegger and Kelly, 1970) and in subsurface features such as caves (Jones and Varnerdoe, 1968).

High-yield wells and wells that penetrate large cavities are of particular interest in settings like the Warrenton area. Existing records (Sanford, 1966) list a well (0-2 in figs. 3 and 5 , and table 2) that penetrates a 40-foot thick cavity in the Warrenton area. There are no quantitative records describing the yield of the well and access is currently limited; however, it was used to supply water for a minnow farm and is reported by local residents to be capable of producing more than $100 \mathrm{gal} / \mathrm{min}$. This well, 0-2, represents a known ground-water bearing zone in the Warrenton area. Other wells in the Warrenton area are known to be adequate for domestic supply and are usually less than 200 feet deep. Several relatively large springs occur in the Warrenton area as well. The most notable of these are Smith Spring and Taylor Spring (fig. 5) which, from historical records (Chandler and Moore, 1987; Johnston, 1933), are known to discharge more than $100 \mathrm{gal} / \mathrm{min}$. These two springs, especially Taylor Spring, sustain flow through extended rainless periods and represent ground-water discharge zones.

Geophysical techniques were used in the Warrenton area in an attempt to obtain further definition of the geohydrologic character of the area. In particular, it was hoped that these methods would produce information concerning the presence of cavities such as those encountered in well 0-2. The gravimetric technique was evaluated by surveying the area surrounding well 0-2 where a known cavity exists. The DC-resistivity technique could not be used in the immediate vicinity of well 0-2 due to physical constraints such as pavement, highways, and buildings. 

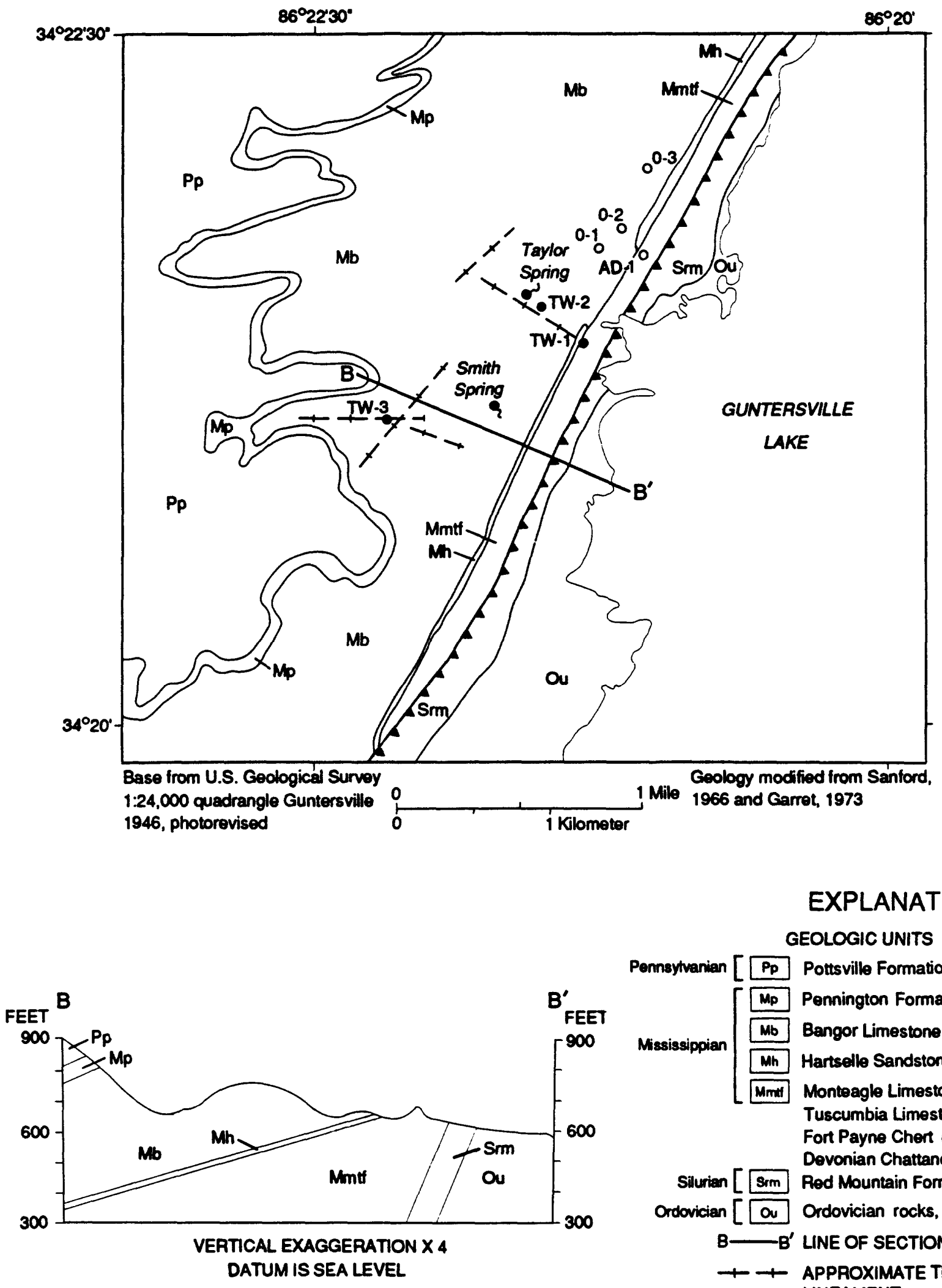

\section{EXPLANATION}

GEOLOGIC UNITS

$$
\begin{aligned}
& \text { Pennsytuanian }\left[\mathrm{Pp}_{\mathrm{p}}\right. \text { Pottsville Formation } \\
& \text { Mississippian }\left[\begin{array}{ll}
\hline \text { Mp } & \text { Pennington Formation } \\
\hline \text { Mb } & \text { Bangor Limestone } \\
\hline \text { Mh } & \text { Hartselle Sandstone } \\
\hline \text { Mmt } & \text { Monteagle Limestone, }
\end{array}\right. \\
& \text { Tuscumbia Limestone, } \\
& \text { Fort Payne Chert (locally includes } \\
& \text { Devonian Chattanooga Shale at base) } \\
& \text { Silurian [ } \mathrm{Sm} \text { Rod Mountain Formation } \\
& \text { Ordovician [ou Ordovician rocks, undifierentiated } \\
& B \longrightarrow B^{\prime} \text { LINE OF SECTION } \\
& +\rightarrow \text { APPROXIMATE TRACE OF } \\
& \text { LINEAMENT } \\
& \checkmark \text { BROWNS VALLEY FAULT } \\
& \text { TW-1 • TEST WELL AND IDENTIFIER } \\
& \text { 0.2 O OBSERVATION WELL AND IDENTIFIER } \\
& 3 \text { SPRING AND IDENTIFIER }
\end{aligned}
$$

Figure 5.--Map showing generalized geology, locations of test wells, and geologic sections in the Warrenton area. 
A gravity survey was run over a 35 foot by 105 foot grid centered over well $0-2$. The results of the gravimetric survey near well 0-2 indicated that the resolution of the readings obtained with the meter were not adequate for the intended purposes. Although certain procedural changes in the survey such as a random visiting pattern and incorporation of multiple readings at several stations within the grid would improve the reliability of such surveys considerably and allow more definitive statements concerning meter resolution, it is still apparent that additional resolution is required. The range of corrected readings obtained was about 500 microgals, a value which is very large in a relative sense, and cannot be reasonably attributed to regional gradients (Woodward and Joestring, 1964) or underground cavities. For instance, assuming a cavity at a depth of 75 feet, a radius of 15 feet, and a density contrast of 2.0 , the following formula may be used to calculate a theoretical anomaly of about 10 microgals for a cavity similar to the one penetrated in well $0-2$.

$$
\gamma-\frac{\omega \sigma z^{3}}{z^{2}}
$$

where : $\gamma$ - relative gravity in microgals

$z$ - depth to center of cavity in feet

$r$ - radius of cavity in feet

$\sigma$ - density contrast

$\omega$ - universal gravitational constant

Doubling the radius increases the calculated anomaly to about 81 microgals which is still roughly an order of magnitude less than the observed range and strongly suggests that the resolution of the survey is not adequate to detect even relatively large cavities. The gravimetric technique was abandoned based on these calculations; however, a more appropriate meter and survey procedure could increase the resolution of the survey and be effective in detecting large and relatively shallow cavities.

A DC-resistivity survey was run just north of well TW-1 (fig. 5). Although a rigorous analysis of the profiling results was not undertaken, the survey, in general, produced very consistent results. By running separate surveys before and after recharge to the ground water system, resistivity breaks associated with the water table in surficial material were identified and there was also some indication of a deeper interface, presumed to represent the bedrock surface; however, there was no indication of cavities. The results of test drilling corroborate the initial assumptions that the DC-resistivity method detected the water table and the bedrock surface. 
Although it is difficult to outline the specific location of the Anniston Lineament Complex in the Warrenton area, the site for TW-1 (fig. 5), is in the vicinity of the projected trace for this feature. However, the trace of a readily-identifiable linear feature which also coincides with Taylor Spring (fig. 5) was the principal factor used in siting TW-1. The geologic maps from Adams and others (1926) and Sanford (1966) (fig. 3) were used for the location of maximum fold flexure on the western side of the Sequatchie anticline and to finalize the site for $T W-1$. It was assumed that in this area, where fold flexure was likely to be greatest, the incidence of fractures would be greatest. The altitude of the site is about 610 feet. Based on the 1966 geologic map (Sanford, 1966) and a Soil Conservation Service survey (U.S. Departinent of Agriculture, 1959) it was anticipated that drilling would penetrate as much as 50 feet of Hartselle Sandstone which would conformably overlie the Monteagle-Fort Payne aquifer.

The total depth of the finished well was 350 feet. Bedrock was penetrated at a depth of 53 feet, and a 55-foot string of casing was set. Before casing was set, the well was producing about $70 \mathrm{gal} / \mathrm{min}$ of turbid water from the unconsolidated material overlying the bedrock. This material was a mixture of alluvial sand and gravel and regolith or residual weathered material from the underlying limestone. The remaining 297 feet of the test well penetrated consolidated limestone. No cuttings of the Hartselle Sandstone were returned during well construction and this has been interpreted to indicate that the test site is actually to the east of the Hartselle Sandstone outcrop as shown in figure 5. No readily apparent formation changes were detected in the cuttings and it is presumed that the well penetrated a relatively steeply dipping section of the Monteagle-Fort Payne aquifer. Cavities as much as 0.5 feet thick at depths of 134 and 254 feet were logged by the driller, and the caliper log indicates additional small cavities at depths of 75 and 212 feet (fig. 6). All cavities yielded water to the well; however, the majority of water seemed to be related to the 0.5-foot cavity at a depth of 254 feet. With the surface cased off and very little air based development, the well produced about $100 \mathrm{gal} / \mathrm{min}$ of turbid water.

TW-2, based on the same linear features used in the TW-1 siting and the proximity of a known ground-water discharge point (Taylor Spring), was sited a short distance north and west of $\mathrm{TW}-1$ (fig. 5). The altitude of the site is about 590 feet. Based on the 1966 geologic map (Sanford, 1966) and formation thicknesses from wells in Madison and Morgan Counties, it was estimated that the base of the Monteagle-Fort Payne aquifer would be at about 550 feet and possibly less if thinning trends to the west reported by Thomas (1972) extend into this area.

The total depth of the finished well was 492 feet. Bedrock was reached at a depth of 41 feet, and a 42-foot string of casing was initially set. The character of the unconsolidated material overlying bedrock was similar to that in $T W-1$, a mixture of alluvial and residual material. The remaining 451 feet of the test well were completed in consolidated limestone, shale, and 

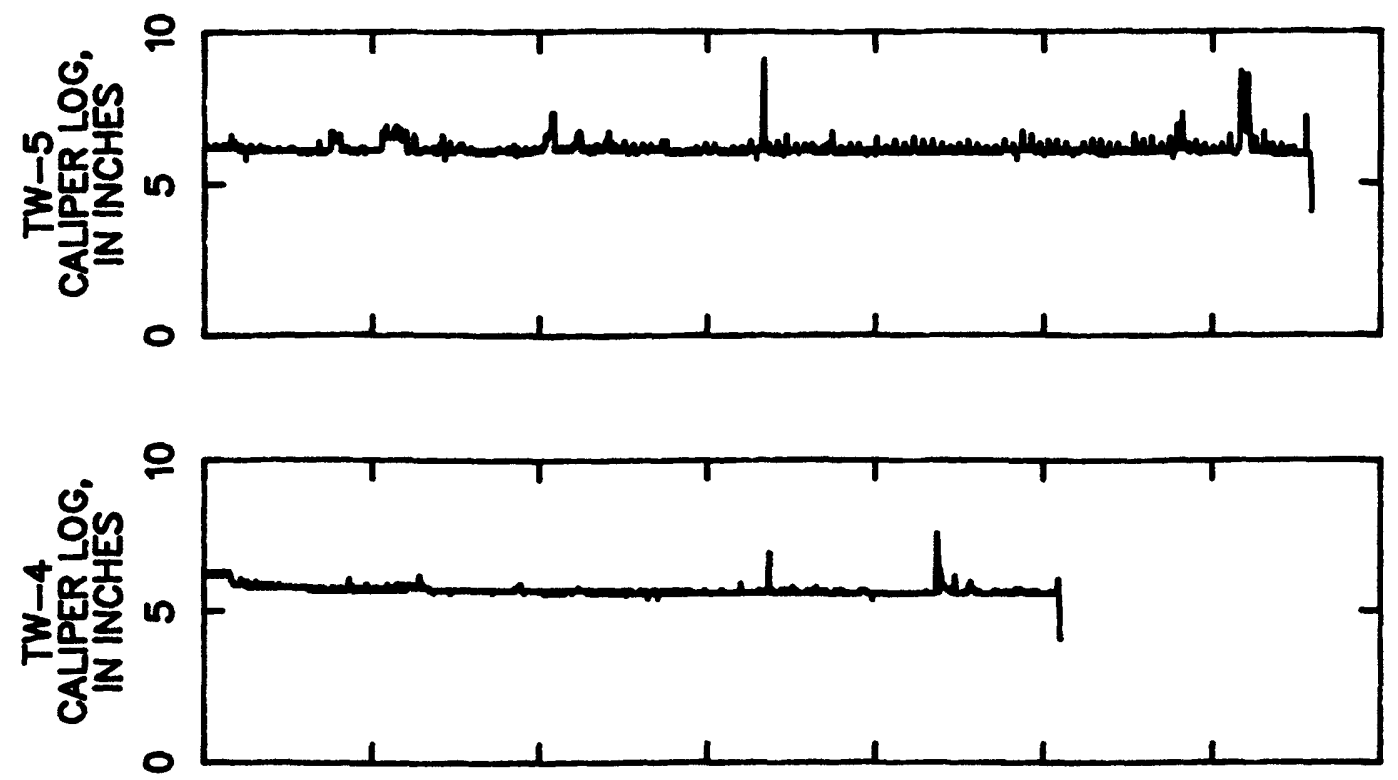

10

을

8

i)

i

$-$

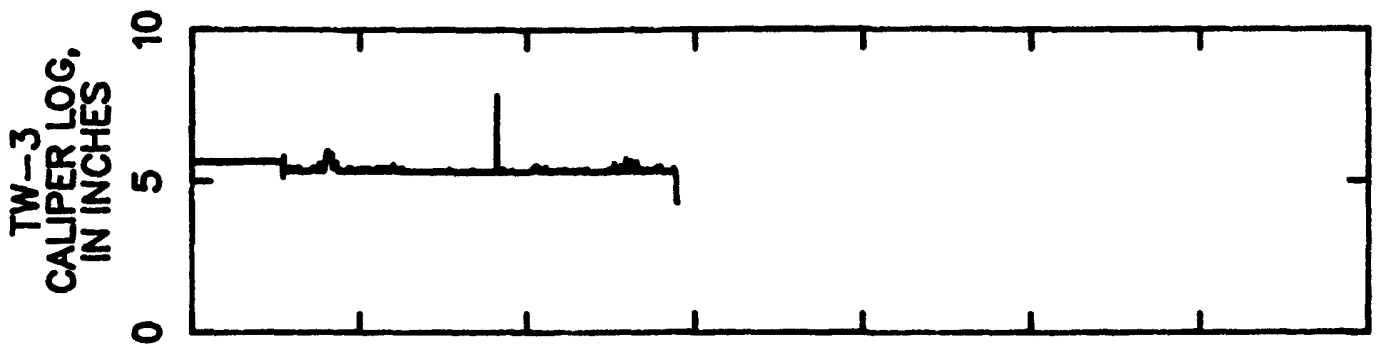

$\stackrel{0}{\overline{0}}$

3

$\stackrel{\infty}{9}$

는

o

음

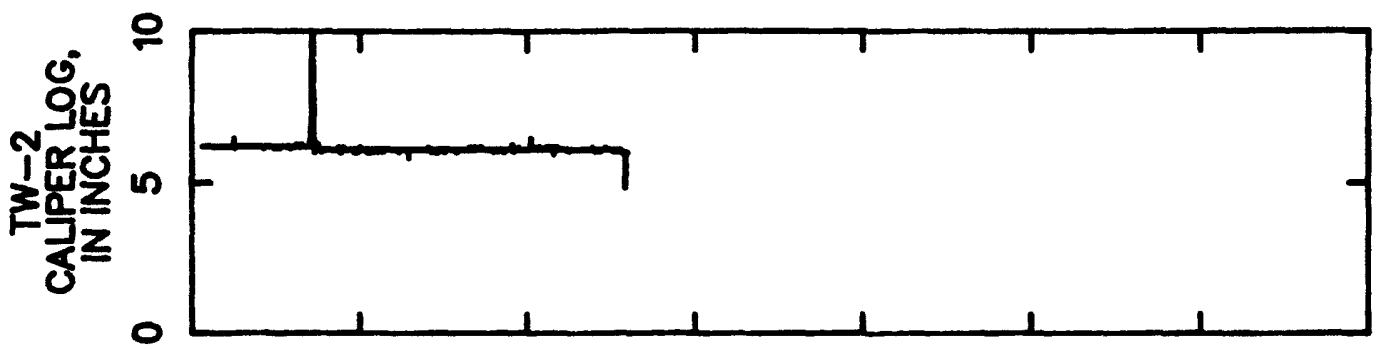

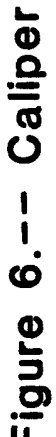

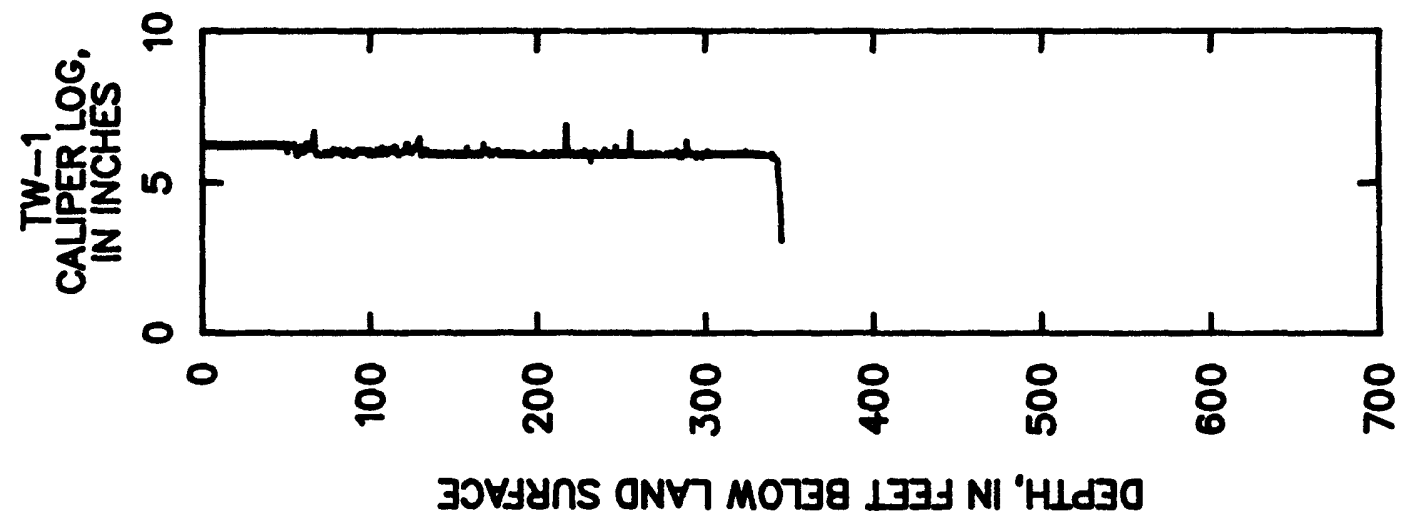


sandstone. A cavity zone consisting almost entirely of a single mud-filled opening was penetrated from 51 feet to about 68 feet. Although circulation was difficult to maintain through this section, the well was producing more than $100 \mathrm{gal} / \mathrm{min}$ of very turbid water. Additional casing was installed to a depth of 71 feet and was effective in improving circulation, but with reduced yield. However, with further drilling, the well was soon again producing greater than $100 \mathrm{gal} / \mathrm{min}$ of very turbid water. This return of water was interpreted to indicate penetration of a network of fractures connected with the cavity zone from 51 to 68 feet.

At 100 feet, approximately 10 feet of Hartselle Sandstone was penetrated; this interval was overlain by a thin fossiliferous zone. With the base of the Hartselle Sandstone at 110 feet, the projected depth for the base of the Fort Payne Chert was about 660 feet. Subtle lithologic changes at depths of 270 and 490 feet correspond to 180- and 200-foot thicknesses, respectively, for the Monteagle Limestone and the Tuscumbia Limestone. The caliper log (fig. 6) was completed to a depth of only 265 feet due to mud filling which occurred while cavities were developed with air. At completion, the well was producing several hundred gallons per minute of very turbid water, presumably from the cavity zone at 51 to 68 feet.

TW-3 was sited based principally on linear features although a known ground-water discharge point, Smith Spring, is also nearby. The site (fig. 5) is south of the projected trace for the Anniston Lineament Complex and also farther west of the Sequatchie anticline than TW-2. The altitude of the site is about 650 feet. Based on the 1966 geologic map (Sanford, 1966), it was estimated that a section of Bangor Limestone would be penetrated and that the Hartselle Sandstone would be penetrated within 150 feet of the surface.

The total depth of the finished well was 309 feet. Bedrock was reached at a depth of 30 feet, and an initial 31 -foot section of casing was set. The unconsolidated material overlying bedrock consisted mostly of alluvial material. A 1-foot thick mud-filled cavity that caused loss of circulation was penetrated at a depth of 44 feet. Additional casing was installed to a depth of 48 feet to regain circulation, and the remaining 264 feet of the test well penetrated consolidated limestone. No cuttings of the Hartselle Sandstone were returned during drilling indicating that the well was completely in the Bangor Limestone. A 0.5 -foot cavity was logged by the driller at 181 feet and the caliper $\log$ indicates several additional small cavities from about 250 to 265 feet (fig. 6). Both of the larger cavities yielded water to the well; the yield of the cavity at 44 feet was difficult to evaluate with compressed air methods due to circulation problems. The cavity at 181 feet yielded about $100 \mathrm{gal} / \mathrm{min}$ of relatively clear water.

The cooperator, City of Arab Waterworks Board, conducted additional drilling and some modification to two of the wells in the Warrenton area. An additional well, $A D-1$, was constructed on property owned by the water department (fig. 5) at an elevation of about 605 feet. The well was very similar to TW-2 in that it had an approximately 20-foot cavity zone at a depth of 70 to 90 feet at about the same elevation as the 17-foot cavity in TW-2. Well AD-1 also penetrated the Hartselle Sandstone at a depth of about 100 feet. 
The casings in two of the Warrenton area test wells, TW-2 and TW-3, were modified. Both of these casings were removed and slotted to provide the wells access to relatively shallow water from cavities which had originally been cased off.

\section{Aquifer Tests}

Initial pumping of wells TW-2, TW-3, and $A D-1$ was conducted to evaluate potential yield as it was decided to conduct step-drawdown tests only on wells yielding more than $100 \mathrm{gal} / \mathrm{min}$. The pump was set twice in $T W-3$; first, without slotted casing to test the deeper cavity at a depth of $181 \mathrm{feet}$, and second, with slotted casing to test the shallow cavity at a depth of 44 feet.

The initial pumping in TW-2 of the 17-foot cavity from 51 to 68 foot depth, with casing slotted, suggested that the well would produce more than $200 \mathrm{gal} / \mathrm{min}$. However, the well bore was filling with sediment from the cavities that had been penetrated and a considerable amount of time, and perhaps additional construction would be required to reduce sediment inflow and properly develop the well.

Initial pumping of the $0.5 \mathrm{ft}$ cavity at 181 feet in $\mathrm{TW}-3$, with the cavity at 44 feet cased off, produced relatively clear water and indicated that excessive sediment would not constrain yield in this well. However, it did not seem that this zone would yield much more than $100 \mathrm{gal} / \mathrm{min}$ and further testing of the cavity was not pursued. Initial pumping of the l-foot cavity from 44 to 45 feet in TW-3 produced less than $100 \mathrm{gal} / \mathrm{min}$ and indicated that excessive sediment would probably be a constraining factor for the production from this cavity.

The initial pumping at $A D-1$ indicated that the well would probably yield in excess of $325 \mathrm{gal} / \mathrm{min}$ from the cavity from 70 to 90 feet and it was decided to conduct a step-drawdown test at this well.

A step-drawdown test consisting of four 120-minute duration steps was conducted at $A D-1$. The initial pumping rate was $100 \mathrm{gal} / \mathrm{min}$ and step increases were made to 150,200 , and $250 \mathrm{gal} / \mathrm{min}$. The turbidity of water from the well increased visibly at the beginning of each step and then decreased through the step. The maximum observed drawdown of 40.13 feet occurred at the end of the fourth step (fig. 7). The specific capacity of the well, based on the average discharge for the test, is about $4.5 \mathrm{gal} / \mathrm{min} / \mathrm{ft}$.

Water levels were measured periodically in $\mathrm{TW}-1$ and $\mathrm{TW}-2$ as well as two domestic wells ( $0-1$ and $0-3$ in fig. 5) during the step-drawdown test at $A D-1$. It was not possible to measure the water level in $0-2$ due to access limitations; however, it is known that the water level was lowered below the pump intake during initial pumping. The results of the water-level measurements and observations indicate that $\mathrm{TW}-2,0-1,0-3$, and $0-2$ have some degree of hydraulic connection with $A D-1$, presumably due to penetration of a relatively widespread cavity system. Three of these wells, TW-2, $A D-1$, and $0-2$, penetrated a large cavity about 20 feet thick, at about the same altitude. Together, these wells define a narrow area about 4,000 feet long parallel to strike that apparently has interconnected cavities in the Bangor aquifer. 


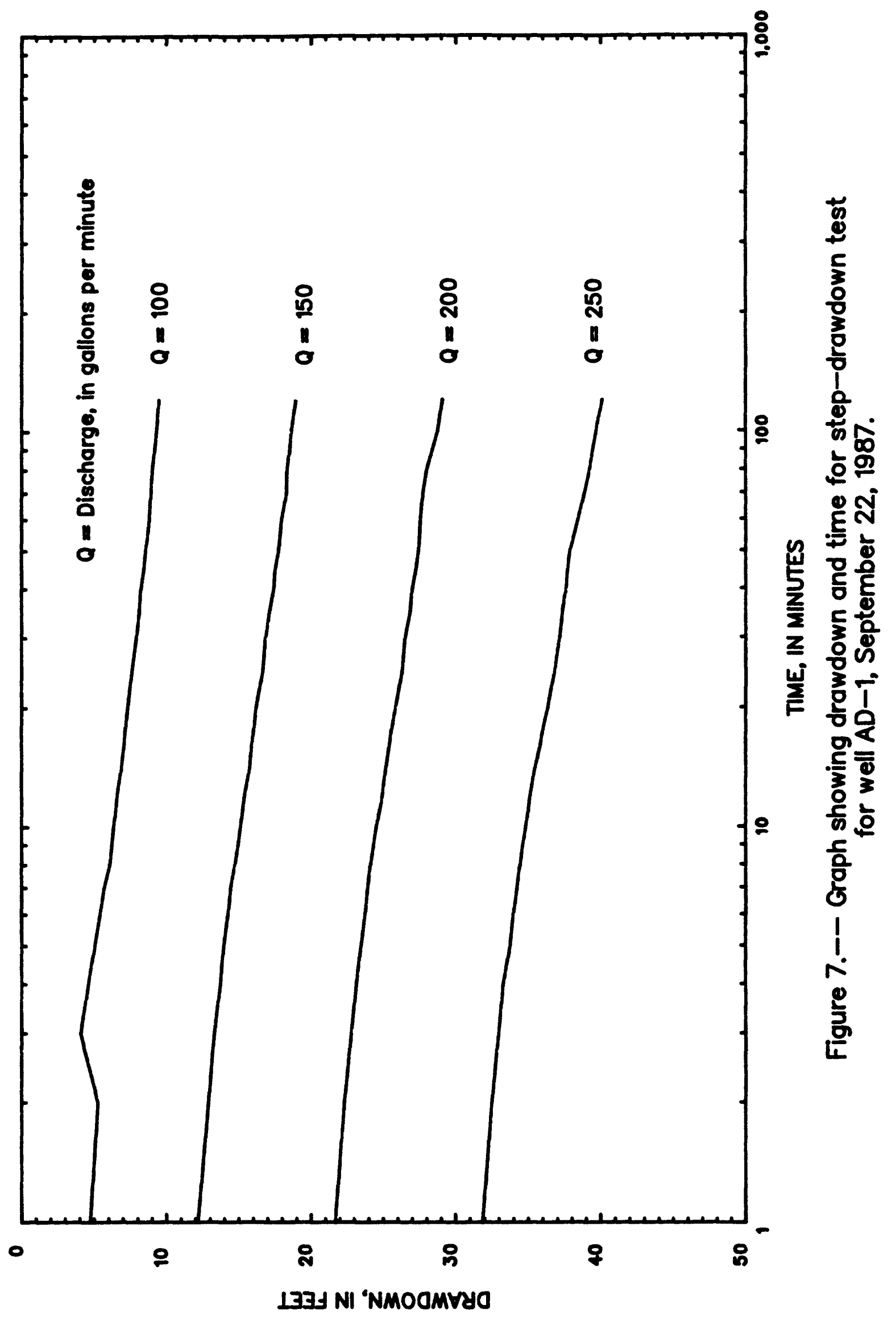


Brindley Mountain Area

The geohydrologic setting in the Brindley Mountain area is representative of the Jackson County mountains and Warrior basin districts or about 80 percent of the study area. Two test wells, TW-1 and TW-2, were constructed in the Brindley Mountain area (fig. 8).

\section{Geohydrologic Reconnaissance}

In the Brindley Mountain area, most wells are less than 200 feet deep in sandstone of the Pennsylvanian Pottsville Formation and and provide quantities of water that are adequate for domestic supply. However, the potential for sustained yield may be very low and, during extended rainless periods, wells may fail to produce water. At some areas on Brindley Mountain, wells completed in the Pottsville Formation, where it is relatively thick and weathered, may produce greater than $100 \mathrm{gal} / \mathrm{min}$ at depths between 200 and 300 feet (table 2) (Sanford, 1966). However, water produced from the Pottsville Formation may require more treatment than other local ground waters due to relatively high iron concentrations. Results of historical chemical analyses show dissolved iron concentrations are commonly greater than $0.3 \mathrm{mg} / \mathrm{L}$ (table 2). Springs also occur in the Brindley Mountain area where confining beds for local perched aquifers crop out. Discharge from these springs is, in general, related to direct runoff and their flow is usually low and poorly sustained.

Hughes Spring and Newsome Sinks (fig. 8) are noteworthy features in the Brindley Mountain area. Hughes Spring occurs near base level where the Bangor Limestone crops out at the southern end of Newsome Sinks. Newsome Sinks, as its name implies, is an area that has a large number of sinks or sinkholes. Newsome Sinks has the configuration of an incised drainage basin with an area of about 7.5 square miles, including the area of surrounding upland surface which drains into the sinks. Drainage within Newsome Sinks is beneath the land surface and Hughes Spring is commonly believed to be the outflow for the subsurface drainage. A series of 24 discharge measurements over a period of 27 years indicates that the discharge of Hughes spring varies considerably from wet to dry seasons much like the discharge of a stream. More importantly, however, six measurements made in August and September indicate that the ground-water discharge or baseflow of the spring is in excess of 150 gal/min. This value is approximately three times the $7 Q_{10}$ a of about 45 gal/min computed using equations developed by Bingham (1982). The high base flow for the spring indicates that ground-water availability may be better in the vicinity of Newsome Sinks than in most of the Brindley Mountain area.

a $7 Q_{10}$ is the lowest mean discharge for 7 consecutive days expected to occur at a recurrence interval of 10 years. 


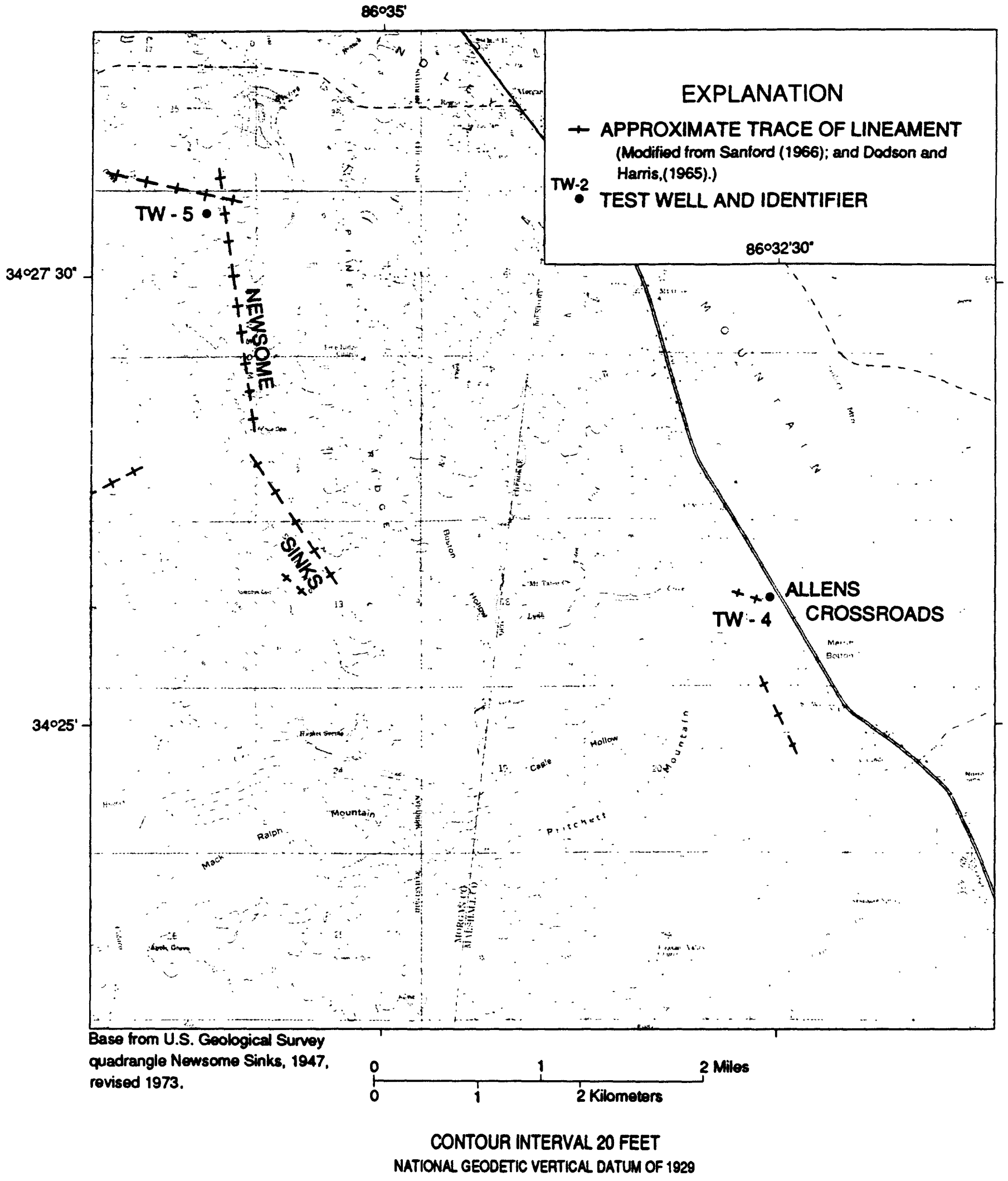

Figure 8.--Map showing locations of test wells in the Brindley Mountain area. 
TW-4 was sited near Allens Crossroads less than 2 miles east of Newsome Sinks because there are several sinks and depressions in the general area. Aerial photography shows subtle features suggesting a linear element near the site for this well as shown in figure 8. Field observations of linear shallow closed contour depressions were used to finalize the site. The altitude of the site is about 930 feet. Based on the 1965 geologic map (Dodson and Harris), it was estimated that the lower part of the Pottsville Formation and the entire section of the Pennington Formation and the Bangor Limestone could be penetrated at a depth of about 500 feet.

The total depth of the well was 520 feet, about 170 feet below base level. Bedrock was penetrated at a depth of 13 feet and a 16-foot string of casing was set. The remaining 507 feet of the well penetrated sandstone, shale, and limestone. Cuttings of the Pottsville Formation consisting of coarse grained sandstone and interbedded shale with some secondary sulfide minerals were returned from the hole from 13 feet to about 80 feet. From 83 feet to about 170 feet, 87 feet of the Pennington Formation, consisting of variegated shales, was penetrated below the Pottsville Formation and above the Bangor Limestone. Beneath the Pennington Formation, from 170 feet to about 480 feet, 310 feet of Bangor Limestone and about 20 feet of the underlying Hartselle Sandstone was penetrated. The driller reported a broken zone at about 335 feet and the caliper $10 g$ indicates an additional cavity at about 450 feet (fig. 6). The finished well produced less than $50 \mathrm{gal} / \mathrm{min}$ from a shallow weathered zone in the Pottsville aquifer.

TW-5 was sited between two branches of Newsome Sinks on strike with the main axis of the sinks and close to the trace of a smaller secondary linear feature (fig. 8). A small spring within Newsome Sinks and roughly on the main axis was also considered in siting the test well. The altitude of the site is about 1,130 feet. Based on the 1965 map (Dodson and Harris), it was estimated that the Monteagle-Fort Payne aquifer would be at a depth of about 550 feet.

The total depth of the well was 672 feet. Bedrock, although weathered, was reached near the surface and a 17-foot string of casing was set. The remaining 655 feet of the well penetrated sandstone, shale, and limestone. The Pennington Formation was reached at a depth of 87 feet and was about 110 feet thick. From 200 feet to about 620 feet, about 420 feet of the Bangor Limestone was penetrated beneath the Pennington Formation. About 30 feet of the Hartselle Sandstone was penetrated at a depth of 620 to 650 feet. The Monteagle-Fort Payne aquifer was reached at a depth of about 650 feet. No cavities were logged by the driller but the caliper log indicates cavities or openings at about $200,340,620$, and 655 feet (fig. 6). The lowermost cavity or opening in the Monteagle-Fort Payne aquifer produced about $70 \mathrm{gal} / \mathrm{min}$. A limited amount of air development caused a noticeable increase in the yield; however, the water was brackish. 
The study area includes two distinct geohydrologic settings typical of those in the Warrenton area and the Brindley Mountain area. In the Warrenton area, rocks of Ordovician through Mississippian age that have been folded and faulted crop out. These rocks include Mississippian carbonate formations such as the Bangor, Monteagle, and Tuscumbia Limestones, and the Fort Payne Chert, which sometimes yield as much as $1,000 \mathrm{gal} / \mathrm{min}$ of potable water to wells in nearby areas. Yields to test wells as great as $325 \mathrm{gal} / \mathrm{min}$ from the Bangor aquifer and $100 \mathrm{gal} / \mathrm{min}$ from the Monteagle-Fort Payne aquifer were obtained. In the Brindley Mountain area, relatively flat lying rocks of Mississippian through Pennsylvanian age crop out. Although the Pottsville Formation of Pennsylvanian age reportedly may yield more than $100 \mathrm{gal} / \mathrm{min}$ of water to wells where it is weathered, the water produced often contains greater than $0.3 \mathrm{mg} / \mathrm{L}$ of dissolved iron. A yield of less than $50 \mathrm{gal} / \mathrm{min}$ was obtained from a test well in the Pottsville aquifer. A test well from the Monteagle-Fort Payne aquifer in the Brindley Mountain area yielded $70 \mathrm{gal} / \mathrm{min}$ of brackish water.

A geohydrologic reconnaissance was conducted in each area and two geophysical techniques were applied in the Warrenton area. The geohydrologic reconnaissance identified several features such as springs, linear surface features on aerial photography, and known water-bearing solution features in the Warrenton area. These features indicate points of ground-water discharge, likely areas for solutional development, and areas where solution processes have developed water-bearing features. A geohydrologic reconnaissance identified similar features in the Brindley Mountain area. Geophysical techniques used to detect solution features in the Warrenton area were not successful in the Brindley Mountain area.

Test-drilling sites were selected in each area after conducting a geohydrologic reconnaissance. The sites were selected based on the presence of known aquifers, proximity of ground-water discharge areas, presence of linear features detected on aerial photography, and, where possible, the existence of known ground-water bearing zones. Three sites were selected for test drilling in the Warrenton area, and an additional site was selected and drilled independently by the cooperator. Two sites were selected for drilling in the Brindley Mountain area. A pump was used to evaluate well capacities for several wells in the Warrenton area.

The results of the test drilling and subsequent pumping of test wells indicate:

1. Carefully-sited test wells constructed in the Warrenton area produced more than $100 \mathrm{gal} / \mathrm{min}$ of water from Mississippian carbonate formations. Sediment, from cavities penetrated in the wells, caused excessive turbidity in some wells.

2. Water levels in four observation wells measured or inferred during a step-drawdown test of a well penetrating a large cavity in the Warrenton area indicate that all five wells are hydraulically connected; indicating the wells may penetrate an interconnected, relatively extensive cavity system at least 4,000 feet in length. 
3. Test wells constructed in the Brindley Mountain area had yields of less than $100 \mathrm{gal} / \mathrm{min}$. The highest yield, about $70 \mathrm{gal} / \mathrm{min}$, was from a small fracture or opening in the Monteagle-Fort Payne aquifer. The quality of the water was brackish. A test well tapping a weathered sandstone in the Pottsville aquifer yielded less than $50 \mathrm{gal} / \mathrm{min}$ of potable water. 


\section{SELECTED REFERENCES}

Adams, G.L., Butts, Charles, Stephenson, L.W., and Cooke, C.W., 1926, Geology of Alabama: Geological Survey of Alabama Special Report 14, 312 p.

Bingham, R.H., 1982, Low-flow characteristics of Alabama streams:

U.S. Geological Survey Water-Supply Paper 2083, 27 p.

Chandler, R.V., and Moore, J.D., 1987, Springs in Alabama: Geological Survey of Alabama Circular 134, 95 p.

Dobrin, M.B., 1976, Introduction to geophysical prospecting: McGraw-Hill Book Company, $630 \mathrm{p}$.

Dodson, C.L., and Harris, W.F., 1965, Geology and ground-water resources of Morgan County, ALabama: Geological Survey of Alabama Bulletin 76, 90 p.

Drahovzal, J.A., and Neathery, T.N., 1971, The middle and upper Ordovician of the Alabama Appalachians: Alabama Geological Society Guidebook for the ninth annual field trip, $240 \mathrm{p}$.

Drahovzal, J.A., Neathery, T.N., and Wielchowsky, C.C., 1975, Significance of selected lineaments in Alabama: Geological Survey of Alabama Reprint Series 34,21 p.

Garrett, W.T., Jr., 1973, Geology of a portion of the Sequatchie Anticline in southern Marshall County, Alabama: Unpublished Masters Thesis submitted to The University of Tennessee.

Johnston, W.D., 1933, Ground water in the Paleozoic rocks of northern Alabama: Geological Survey of Alabama Special Report 16, 414 p.

Jones, W.B., and Varnedoe, W.W., 1968, Caves of Madison County, Alabama: Geological Survey of Alabama Circular 52, 128 p.

Moffet, T.B., and Bossong, C.R., 1981, Hydrologic and geologic data for waterresources management in Madison County, Alabama 1974-78: Geological Survey of Alabama Open-File Report, 1981, 198 p.

Sanford, T.H., 1966, Ground water in Marshall County, Alabama: Geological Survey of Alabama Bulletin 85, $66 \mathrm{p}$.

Sapp, C.D., and Emplaincourt, J., 1975, Physiographic regions of Alabama: Geological Survey of Alabama Special Map 168.

Smith, D.L., and Randazzo, A.F., 1975, Detection of subsurface solution cavities in Florida using electrical resistivity measurements: Southeastern Geology, v. 16, p. 227-240.

Sonderegger, J.L., and Kelly, J.C., 1970, Hydrology of limestone terranes, geologic investigations: Geological Survey of Alabama Bulletin 94B, 146 p. 
Stringfield, V.T., LaMoreaux, P.E., and LeGrand, H.E., 1974, Karst and Paleo hydrology of carbonate rock terranes in semiarid and arid regions with a comparison to humid karst of Alabama: Geological Survey of Alabama Bulletin 105, $106 \mathrm{p}$.

Tennessee Valley Authority, 1954, Engineering data TVA water control projects and other major hydro developments in the Tennessee and Cumberland valleys: Technical Monograph No. 55, 473 p.

Thomas, W.A., 1972, Mississippian stratigraphy of Alabama: Geological Survey of Alabama Monograph 12, $121 \mathrm{p}$.

Thornbury, W.D., 1965, Regional geomorphology of the United States: John Wiley and Sons, Inc., $609 \mathrm{p}$.

U.S. Department of Agriculture, 1959, Soil survey, Marshall County, Alabama: U.S. Department of Agriculture Soil Survey series 1956, no. 2. 61 p.

U.S. Department of Commerce, 1985, Local climatological data, annual summary: National Oceanic and Atmospheric Administration, published annually.

U.S. Geological Survey, 1929-1976, Water resources data for Alabama, 1976, 1986: U.S Geological Survey water-data reports, published annually.

Woodward, G.P., and Joestring, H.R., 1964, Bouguer gravity anomaly map of the United States excluding Hawaii and Alaska: American Geophysical Union and U.S. Geological Survey, $1: 2,500,000$.

Zohdy, A.A.R., Eaton, G.P., and Mabey, D.R., 1974, Application of surface geophysics to ground-water investigations: Techniques of Water Resources Investigations of the U.S. Geological Survey, Book 2, Chapter 1, 116 p.

Zurawski, A., 1978, Summary appraisals of the Nation's ground-water resources: U.S. Geological Survey, Professional Paper 813-L, 35 p. 